\title{
"Cuerpo de Telégrafos": First Attempts to Create a Professional Body for Electrical Communications in Spain
}

\author{
Antonio Pérez Yuste \\ Dep. of Communications and Video \& Audio Engineering \\ Technical University of Madrid, UPM \\ Madrid, Spain \\ antonio.perez@upm.es
}

\author{
Olga Pérez Sanjuán \\ Spanish Association of Telecommunication Engineers, \\ AEIT \\ Madrid, Spain \\ olgaps@iies.es
}

\begin{abstract}
The Body of Telegraphists ("Cuerpo de Telégrafos", in Spanish) was established in Spain in 1856 in order to operate the electric telegraph service and later to develop a national-wide telegraph network. The origins of this professional body and the way it was formed with people from the optical telegraphy field of activity will be described. It will also be explained how these people were educated in techniques and methods related to electrical telegraphy. In addition, it will be described how the creation of the Body of Telegraphists caused a conflict with the Body of Civil Engineers, which was the responsible for the development of the optical telegraph network.
\end{abstract}

Keywords - Cuerpo de Telégrafos; Body of Telegraphists; Salvá; Mathé; Queen Isabel II of Spain; Espartero; Narváez; Electrical Engineering; Civil Engineering.

\section{INTRODUCTION}

The Body of Telegraphists ("Cuerpo de Telégrafos", in Spanish) was established in Spain, in 1856, in order to manage and operate the electric telegraph service in a first moment, and later to build and develop a national-wide electric telegraph network. That Body was set up as a technical expert group of people with the abilities and knowledge required to carry out this kind of work [1].

The Body of Telegraphists was incorporated as a Civil Servant Body to the Ministry of Interior (a Department of the Spanish Government Executive Branch dedicated to State Administrations Affairs and National Security), being the first group in obtaining a nationally recognized professional qualification for the development of electrical communications in Spain. That was a long time before first Spanish Telecommunication Engineers were graduated from the Official School of Telegraphy, in 1920, and a long time before profession of Telecommunication Engineering was officially regulated by Royal Decree, in 1931 [2].

The aim of this paper is to describe the origins of this Professional Body and the way it was originally formed with people who came from the optical telegraphy field of activity. It will also be explained how these people was educated in techniques and methods related to electrical telegraphy thanks to a technical school created for this particular purpose. Indeed, optical telegraphists who attended this school were involved in the development of the first long distance telegraph line from Madrid, located in the center of Spain, to Irún, a small village in north of Spain, at the French border, with a total length of 613 kilometers.

In addition, it will be described how the creation of the Body of Telegraphists caused a serious conflict with the Body of Civil Engineers, which was the group responsible for the development of the optical telegraph network. So the controversy was that the aforementioned Telegraph School was dissolved after finishing the works of the Madrid-Irún line and, in addition, professional qualifications to develop electric telegraph lines were temporally transferred to the Body of Civil Engineers.

\section{SPAIN IN THE $19^{\text {TH }}$ CENTURY}

The $19^{\text {th }}$ Century was a dramatic period in the history of Spain. It began with a bloody Liberation War upon the occupation of the Iberian Peninsula by Napoleonic troops in 1808 , and ended with the loss of the last Spanish colonial possessions in Cuba, Puerto Rico, the Philippines and Guam in 1898 [3].

Between both dates, Spain was a country in a permanent turmoil, with three civil wars (known as Carlists Wars), several wars of independence in the Spanish colonies in the Americas, the overthrow of the Spanish Monarchy of Queen Isabel II (she was forced to flee from Madrid), the proclamation of the First Spanish Republic (which lasted for 22 months), a coup to restore the Monarchy again (to establish Alfonso XII, the son of Isabel II, as King of Spain), and the emergence of Anarchosyndicalism movements (as a matter of fact, anarchist trade union federations were of special importance in Spain at the time).

The nineteenth century political turmoil in Spain coincided with a severe internal economic crisis, causing the Industrial Revolution came to Spain later than in other European countries. This was the case of electric communications, where first practical essays were not carried out until the decade of the 1850 's. In spite of this lack, a big effort was made to catch up 
with more developed countries, achieving a whole nationalwide electric telegraph network by 1865 .

\section{EARLY ELECTRIC TELEGRAPHY IN SPAIN}

The father of electrical telegraphy in Spain was Francisco Salvá y Campillo (1751-1828), shown in figure 1. Five years before the Polish Samuel Thomas von Sömmering demonstrated his electro-chemical telegraph to the Munich Academy of Sciences, Salvá proposed a very innovative electric telegraph system based on two key discoveries: the Volta's electric battery to produce a steady and lasting electric current, and the electrolysis process leading to the decomposition of water, found out by William Nicholson and Anthony Carlisle, to detect such a current. Salvá put both phenomena together in order to devise a new type of electric telegraph that he reported to the Barcelona Academy of Sciences, Spain, on February 1804.

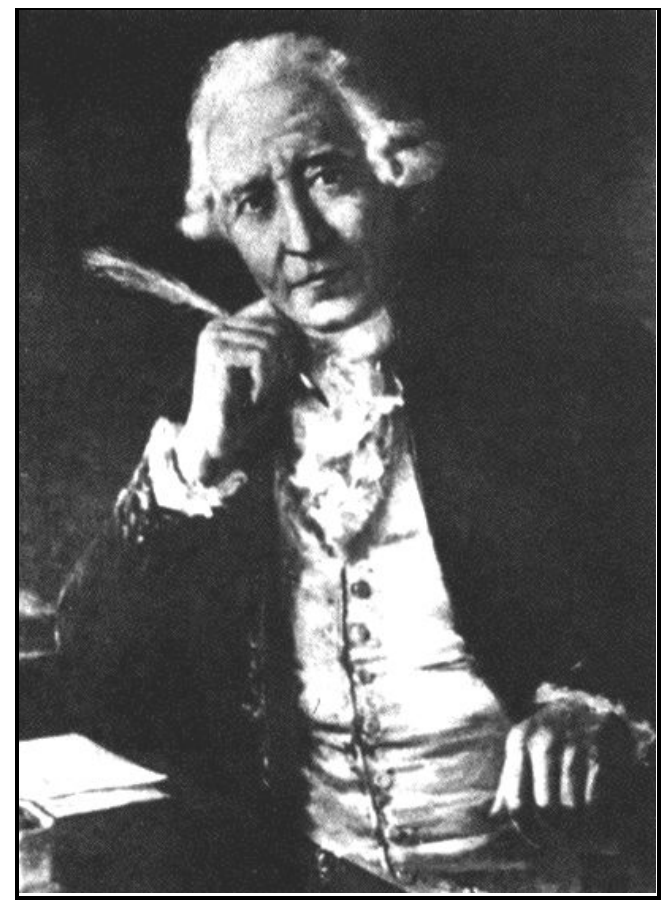

Figure 1. Portrait of Francisco Salvá y Campillo painted by José María Marqués in 1900. Source: Eurotelecom-90 [4].

He began his report by making a review about the state of the art in optical telegraphy, with special references to the line projected and constructed by Agustín de Betancourt (17581824) between Madrid and Aranjuez, a Real Site 50 kilometers away from Madrid. He also mentioned his two previous telegraph systems based on static electricity and galvanic electricity, referring that electric telegraphs were more favorable for long distance communication than optical telegraphs.

Salvá suggested a way to encode two different signals with one jar of water, by only changing the polarity of the voltage applied to the ends of the wires submerged in water, in such a way that hydrogen gas produced by electrolysis would be seen to bubble at one end up or at the other one, depending on the polarity of the battery.

With this idea in his mind, he made use of several circuits with a common return wire to encode so many signals as required, so it is not very difficult to calculate how many wires would be required to encode a given number of signals. Figure 2 shows an artist view of Salvá's electric telegraph as was drawn by Antonino Suárez Saavedra in his book published in 1880 [5].

For more information about life and work of Francisco Salvá y Campillo and a more detailed description on how his electric telegraph worked, please refer to the Proceedings of the IEEE Histelcon Conference held in Paris on October 2008 [6].

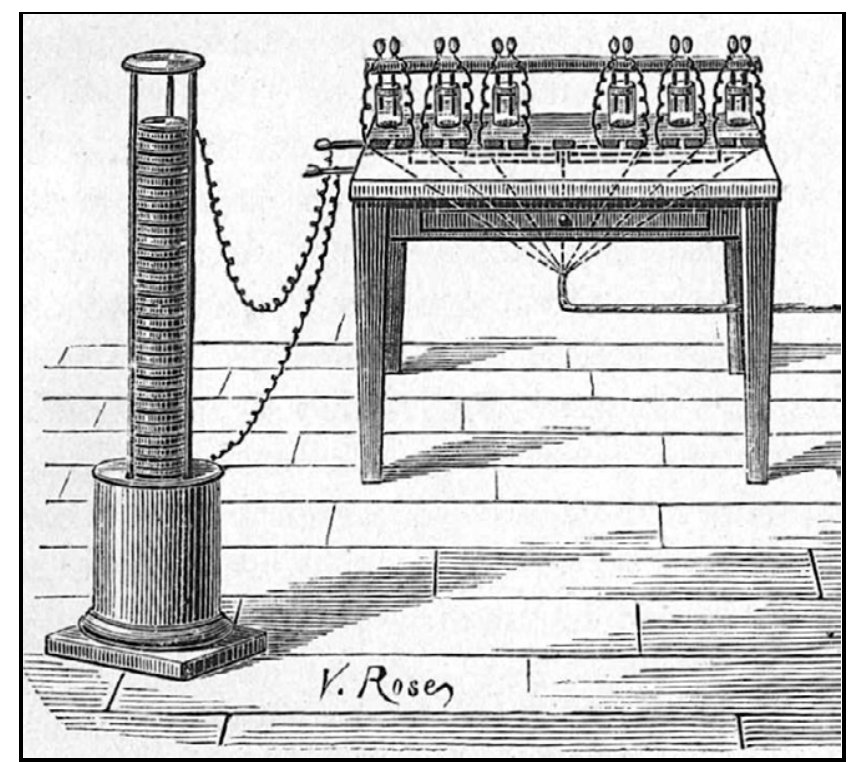

Figure 2. This is a view of Salvá's Electric Telegraph as was imagined by A. Suárez Saavedra. Source: Suárez Saavedra-1880 [5]

After Salvá, no other experience in electrical telegraphy was carried out in Spain for a long time. Instead, a nationalwide optical telegraph network was deployed all over the country from 1844 to 1853 , in a period of time when electric telegraphs were already being set up in some other countries abroad. Only when first railroads began to be introduced in Spain from 1851 onwards, electrical telegraphy became considered as a way to save money and increase safety of trains. The first telegraph line was laid in 1852 between Madrid and Aranjuez, going along the railroad track. It was first operated by private investors but, due to continuous malfunction, the property was finally handed over to the National Public Administration, being directly managed by the Ministry of Public Works.

The Spanish Government soon realized the superiority of electric telegraphs over optical ones. Therefore, the Director General of the Spanish Optical Telegraphs, José María Mathé, shown in figure 3, was commissioned to visit France, Belgium, England and Germany in 1852 in order to learn more on the state of the art in electrical telegraphy and establish an electric telegraph service in Spain. His mission abroad lasted for three 
months and, after returning, he devised a plan to create an educative center to teaching the deployment of telegraph lines and the operation of the transmitting and receiving instruments.

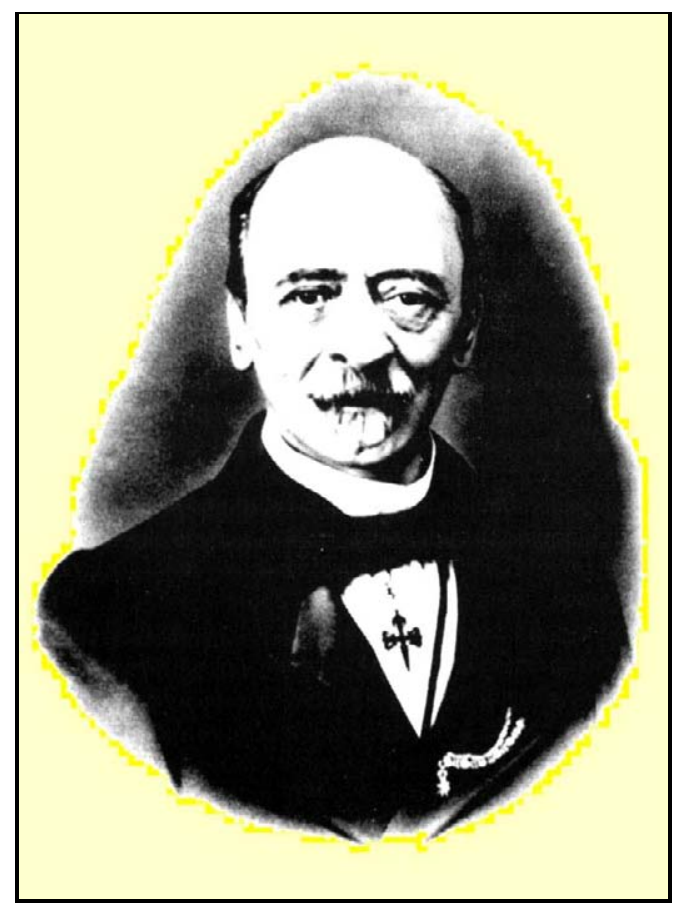

Figure 3. Portrait of José María Mathé, Director General of the Spanish Optical Telegraphs in 1852. Source: Olivé-2004 [1].

Upon the information collected by Mathé, the Spanish Government passed a Royal Decree on November 1852, authorizing the establishment of an electric telegraph line connecting the city of Madrid with Irún, a small village in the north of Spain at the border with France, going through the cities of Guadalajara, Zaragoza, Pamplona and San Sebastián [7]. Aerial wires suspended on wooden posts, instead of underground cables, and Wheatstone two needle telegraph instruments, instead of Morse transmitters and receivers, were selected for that occasion. The projected line had 585 kilometers long, following the blue path drawn on the map shown in figure 4.

In accordance with the aforementioned Royal Decree, the deployment of the line had to be carried out by the Ministry of Public Works under the supervision of José María Mathé (Director General of Optical Telegraphs), corresponding to the Ministry of Interior (which was the executive branch responsible for policing, national security, and immigration matters), on the other hand, the operation of the service provided through the line and the organization of the attached staff, as well as the line maintenance duty.

Such a division caused a big confusion that was even more when, one year later, in 1853, the budget for the construction of the telegraph line was transferred from the Ministry of Public Works to the Ministry of Interior, by using an amount of money that had been previously assigned, but not wasted, to the development of optical telegraphs [8]. Thus, although the Ministry of Public Works was responsible for the construction of the line, the money was really under the control of the Ministry of Interior, which was indeed the responsible for its operation and maintenance, as said before.

At that time, there was actually no idea about the market model to apply for telegraphy in Spain, although general opinion was more favorable towards a public exploitation rather than to a private one, as was usual in other European countries abroad.

To the Ministry of Public Works, the key question was who could deploy telegraph lines but, to the Ministry of Interior, the key question was instead who could operate telegraph lines. To the Ministry of Public Works, Civil Engineers were the only professional group with a capacity to develop those lines and, in addition, the skills required to operate and maintain them. In fact, Civil Engineers understood telegraphy as part of their professional competencies, as they really thought that was some kind of transportation mean, such as a bridge or a canal.

But, to the Ministry of Interior, electric telegraphs were a new technical discipline and, for this reason, a new professional group was required to operate and maintain electric telegraphs and, if needed, to develop the requested network too. That was the rivalry between both Ministries at that time and it would be so for a long.

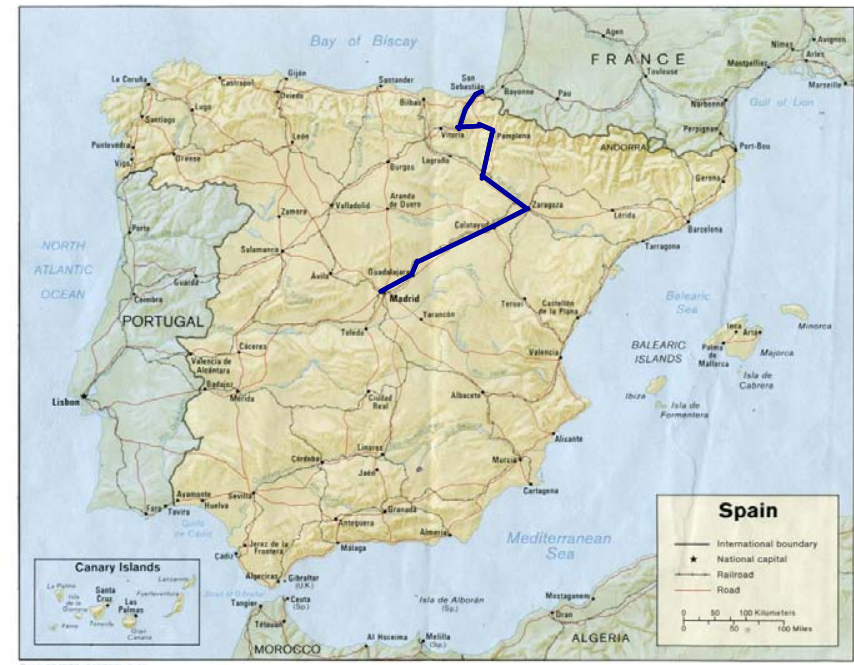

Figure 4. First long distance telegraph line laid in Spain.

\section{THE TELEGRAPH SCHOOL, 1852}

In spite of the opinion of Civil Engineers, there were very few people who really were able to develop the projected telegraph line. That was the reason why, by following the advice of José María Mathé, the Ministry of Interior promoted the creation of a public Telegraph School on October 1852, just one month before passing the Royal Decree ordering the laying of the line [9].

The Telegraph School was placed in an abandoned building that had housed the first optical telegraph tower of the MadridAranjuez line some years before. That building was located at the "Buen Retiro" Park which was, at that time, a royal property area placed in the outskirts of Madrid. The three-story 
building where the Telegraph School was originally sited is shown in figure 5 , as it is at the present time.

The Spanish historian Sebastián Olivé refers an early inventory document coming from this building that contained some entries referring tables, chairs and other different objects; among them two telegraph instruments [1]. Probably, those apparatus might be two 2-needles Wheatstone telegraph equipments, as they were the type of telegraph used in Spain at that time, before the introduction of Morse telegraph equipments.

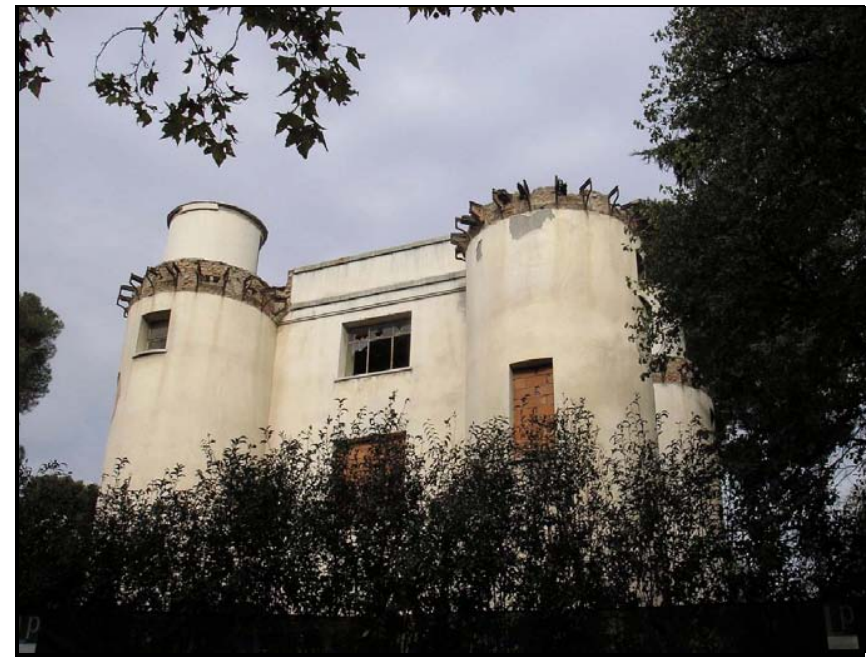

Figure 5. Present view of the first Telegraph School in Madrid. Source: Santiago Rodríguez Guillén.

Stock of materials began on March 1854. In early June 1854 , the line from Madrid to Guadalajara was ended and in the fifth day of that month the first telegram was sent from the first city to the second one. On August 11, the line was run to the city of Zaragoza; on October 18, was connected to Pamplona; on October 22, to San Sebastián; and, finally, came into Irún on October 27 [5]. The line was 613 kilometers long, 28 kilometers larger than the projected length, and was hanged on 1,297 wooden poles [10]. The first telegram, from Madrid to Paris, was sent through the new line on November 8. It consisted on a long text, reproducing the Queen's address at the opening of the parliament [1].

The Telegraph School was intimately related to the telegraph line in construction. Indeed, there were different work groups in operation at the same time. A group entered the School for a two months training period, after which the students were appointed to a certain place for the deployment of a piece of line. Then, a new group entered the School, was taught again, and appointed to a different place, and so forth.

Every group was headed by an Army Reserve Major of Engineers (an intermediate military rank between captain and colonel) who acted as an instructor when he was at the School, and as a manager when he was at work place. At the same time, all Majors reported to José María Mathé, Director General of Optical Telegraphs and an Army Reserve Brigadier of Engineers (an intermediate military rank between colonel and general), who was really the project leader and the person who was trying to create a "de-facto" professional body for electrical telegraphy.

In any case, the organization mirrored a military-like structure, what gives the idea of telegraphy as a valuable instrument to guarantee public order and security. In particular, theses questions turned into transcendent issues in a turmoil situation, such as those ones happened in Spain during nineteenth century. So it was as the Ministry of Interior gained control over telegraphs, although it would still take five years to get it.

\section{THE FIRST TELEGRAPH ACT, 1855}

With the telegraph line from Madrid to the French border still in construction and the Telegraph School still preparing students to deploy that line, a coup took place on July 1854 in order to force the government's resignation, under control of Moderate Party for the last ten years. Queen Isabel II then appointed to General Espartero, shown in figure 6, as Prime Minister, who selected people coming from Progressive Party to set up a new completely different Government.

Political criteria then changed and Telegraph Policy was revised, but the old rivalry between the Ministry of Public Works and the Ministry of Interior still went on. In 1855, the Ministry of Interior was coming up with a Telegraph Bill when the Ministry of Public Works took that opportunity to gain control over the telegraph system by claiming professional competencies only for Civil Engineers and calling for the close of the Telegraph School created two years before [11]. When the Spanish House of Representatives passed the Bill on April 22, 1855, the resulting Telegraph Act conceded a momentary victory to the Ministry of Public Works.

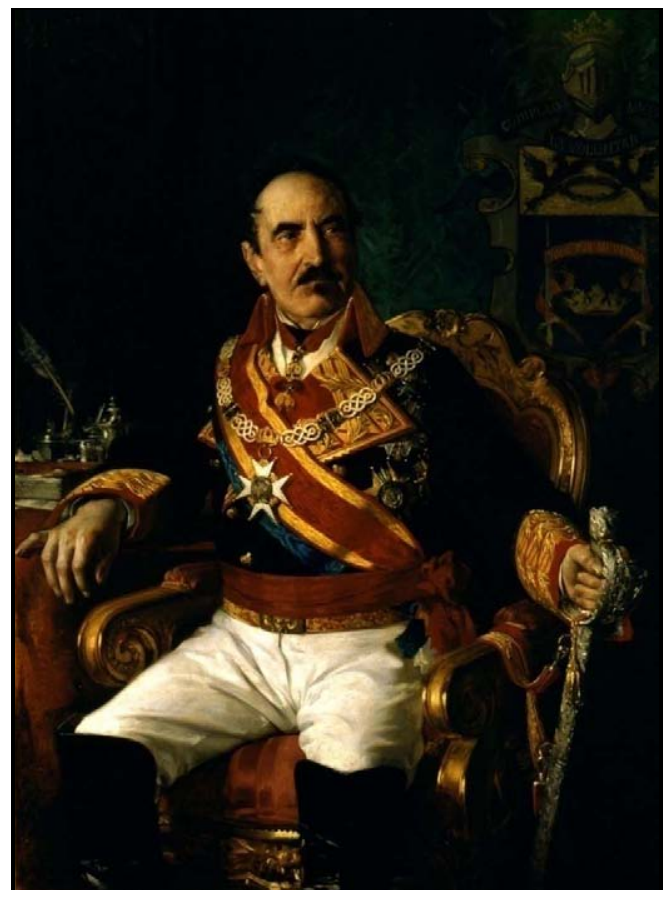

Figure 6. Portrait of General Espartero, Prime Minister after 1854 coup. Source: Spanish House of Representatives. 
Professional competencies for the development of electric telegraphs were transferred to Civil Engineers and all telegraph files and projects were moved from the Ministry of Interior to the Ministry of Public Works, which took control over the whole electric telegraph network. The 1855 Telegraph Act also described a set of five new long distance telegraph lines to be developed in next years, including a budget for their construction.

The Telegraph School was closed but the Minister of Interior, Francisco Santa Cruz, at least, obtained one concession. That was the right to create a Body of Telegraphists depending of his own Ministry. This could be seen as a little victory at a first sight but, at the end, it represented the first battle to 'win the war'.

The Telegraph Act caused a big controversy in media and a serious unrest in society. Some news said the Director General of Optical Telegraphs, who has been responsible for the development of electric telegraphs from the very beginning, would be fired very soon. At the same time, other news talked about some lobbying practices of Civil Engineers and accused the Prime Minister of acting in favor of his son-in-law, Cipriano Segundo Montesino, who was Director General of Public Works at that time [1]. The first thing never happened, and the second one was never probed.

\section{THE BODY OF TELEGRAPHISTS, 1856}

Last day of March 1856, the new Minister of Interior, Patricio de la Escosura, was finally able to pass a Royal Decree including the first Regulation for the Body of Telegraphist. A "de-jure" creation of this new professional Body was established and a personnel structure with a Director General as Head of the organization was included [12]. However, the Regulation could not come into effect immediately, having to wait for a new Prime Minister.

Popularity of General Espartero was falling down quickly, so Queen Isabel II chose a new Prime Minister to take over the Government, once more, on July 1856.

The new Prime Minister, Leopoldo O'Donell, and his Minister of Interior, Antonio de los Ríos Rosas, rapidly appointed José María Mathé to serve as Director General of Telegraphs, both optical and electric [13]. In addition, he did the Body of Telegraphist Regulation came into effect on August 1, 1856 [14]. Key issues of that Regulation were:

- Electrical Telegraphy was considered as a public service, corresponding to the National Public Administration the development and operation of the service.

- A Professional Body of Telegraphists was formally created to operate and maintain the national telegraph network.

- The enrollment to the Body of Telegraphists was based on a compulsory entrance examination.

Optical Telegraphists were transferred to the new Professional Body and a first call for examination was done to recruit new people. Civil Engineers, Mines Engineers,
Industrial Engineers and Forest Engineers were excepted from the examination but, to those who were not excepted, some private academies began to emerge with the aim to prepare them for the examination. As a result, there were enough people available to apply for a "telegraph technician" post when the first call was done.

The Body of Telegraphist was the first professional body for electrical communications in Spain. It was divided in three different professional categories: the Directive and Technical Staff, the Technical Subordinate Staff, and the Security and Services Subordinate Staff. The Head of the Organization was a Director General, position to which José María Mathé was appointed.

There were two different entrance examinations: one for the Directive and Technical Staff, and other one completely different for the Technical Subordinate Staff. In the first case, people who passed the entrance examination were initially posted for Vice Director of Telegraph Section, from where they could be promoted to a higher position. In the second case, people who passed the entrance examination were initially posted for Telegraphist $3^{\text {rd }}$ Class, from where they could be promoted to Telegraphist $2^{\text {nd }}$ Class first, Telegraphist $1^{\text {st }}$ Class then, Administrative Section Officer afterwards and, finally, to Station Director. Promotion from the Technical Subordinate Staff category to the Directive and Technical Staff category seldom happened in practice.

Only people applying to become part of the Security and Services Subordinate Staff did not need to pass any examination to be hired.

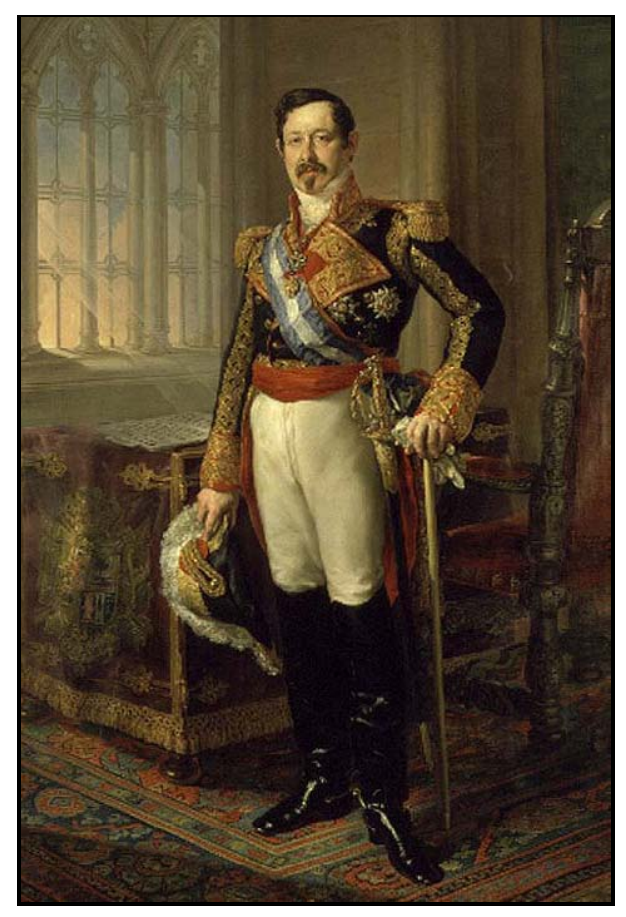

Figure 7. Ramón María Narváez, Prime Minister when professional competencies in Telegraphy were returned to the Ministry of Interior. Source: Valencia Museum of Fine Arts, Spain. 
1857 was the year of a major boost for electric telegraphs in Spain. That year, nearly all telegraph lines included in the 1855 Telegraph Act were ended. The controversy between the Ministry of Interior and the Ministry of Public Works was still alive and, as a consequence, telegraph deployment and telegraph operation duties were often not coordinated each other.

A new government crisis brought a new Prime Minister called Ramón María Narváez (see figure 7). Narváez was more receptive to the Body of Telegraphists demands and, on April 1857, he passed a Royal Decree returning all telegraph professional competencies to the Ministry of Interior [15]. That decision was very welcomed in the Ministry of Interior but very criticized in the Ministry of Public Works. Nevertheless, the most important thing is that was never changed again over the coming years. So it was as the Body of Telegraphist finally gained a complete control over the electric telegraph system, putting an end to a five years' rivalry between both Ministries.

The Body of Telegraphists then changed the star configuration of the telegraph network, with its mid-point in Madrid, to a national-wide mesh configuration in order to get, at least, two paths for connecting every province capital. The first step to do so was connecting the end points of the original star.

Map in figure 8 shows the state of the Spanish telegraph network in late 1857 , three years after concluding the telegraph line construction between Madrid and the French border. At that moment, there were $5,381 \mathrm{Km}$ telegraph lines deployed, 101 telegraph stations and 42 of 50 province capitals connected. That year, optical telegraphs were definitively abandoned and electric telegraphs began to be considered as a useful and usual communication media for journalists, politicians and business people in Spain.

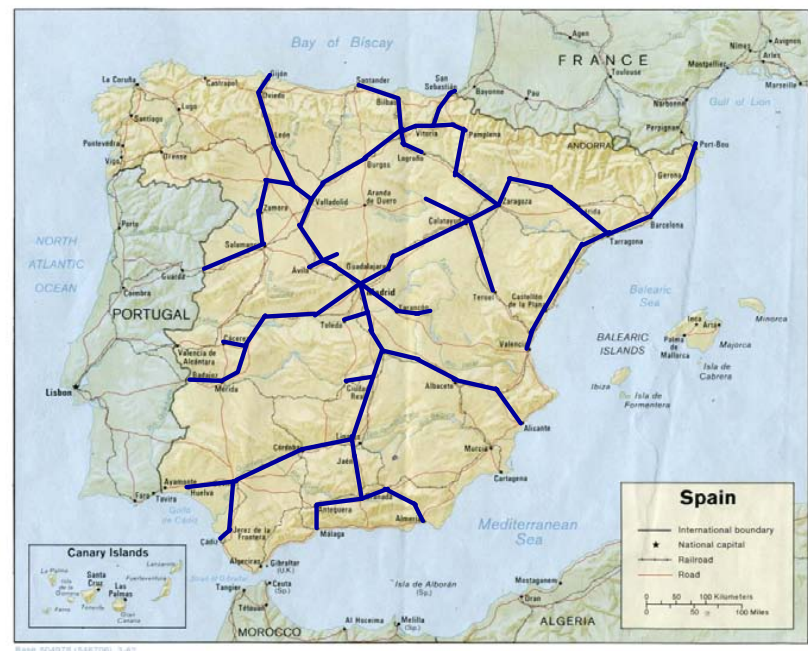

Figure 8. State of the telegraph network in Spain in late 1857.

\section{The Telegraph SPECIAL ACADEMY, 1865}

Although professional competencies in relation to electric telegraphs were actually conferred to the people forming the Body of Telegraphists, Telegraphy was not indeed a higher education degree but, even less, an Engineering discipline. Telegraphists, however, claimed to be considered as Engineers although they really were not. However, rest of Engineers: Civil, Industrial, Mines, Forest, etc., were very reluctant to let them getting that status.

Narváez, on the other hand, still continued with his support to Telegraphists and by December 1864, his Minister of Interior, Luis González Bravo, proposed a new organization for the Body of Telegraphists, passing a Royal Decree where a three year course in telegraphy was required to enter the Body of Telegraphist. This course had to be taken in a Special Academy that was expected to be created very soon [16].

Indeed, the Academy was formally incorporated on February 1865 with a Regulation saying that graduate students could enter the Body of Telegraphists with a professional level "equivalent" to an Engineer. This question caused a great controversy among "real" Engineers who performed such a strong lobbying that the situation only stayed for one year.

Taking advantage of a new Prime Minister taking over, a new Regulation was passed on June 1866 avoiding that graduate students coming from the Telegraph Special Academy were considered as Engineers, putting a bitter end to a beautiful dream [17].

In spite of that setback, the telegraph progress in Spain was quite good by 1865 . But, unfortunately, coming new events caused a serious slowdown onwards in the growth rate.

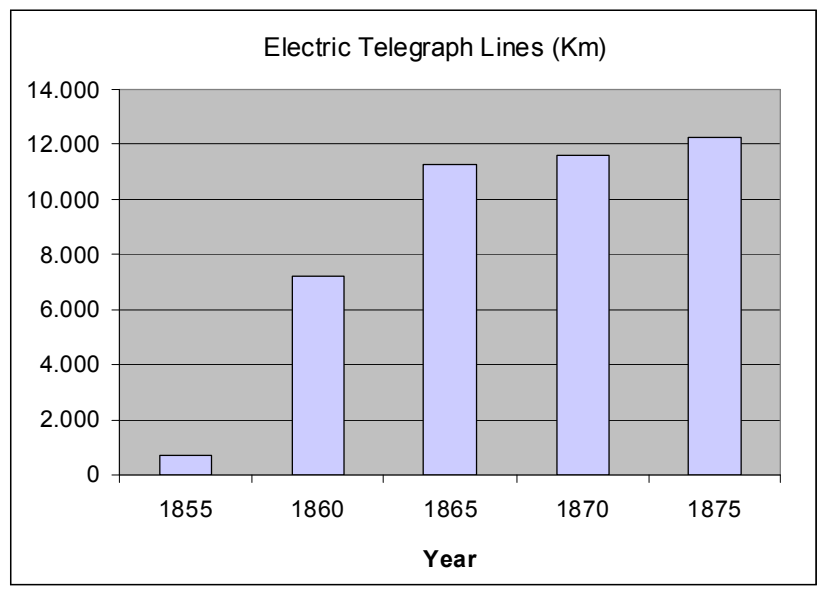

Figure 9. Evolution of the electric telegraph lines (total length) in the first 20 years of existence.

A revolution rose against Isabel II Monarchy in 1868 . The Queen was overthrown and a new King, Amadeo de Saboya, was elected by the Spanish House of Representatives as Head of the State in 1870 . He was the King of Spain only two years: from 1871 to 1873 . He was considered as a foreign King and had no popular support, so he finally resigned, considering Spaniards ungovernable. After that, the first Republic in the history of Spain was proclaimed. However a new coup happened one year later and the Monarchy was restored with King Alfonso XII, son of Queen Isabel II, as new Head of State. Political stability turned then into a key issue in the country and a Conservative regime was firmly installed in 
politics in coming years. Particularly, nothing changed in telegraphy for many years, as new communication technologies came into use: telephony, wireless telegraphy, radiocommunications, broadcasting, configuring a new technical field that was known as "Telecommunications".

Finally, after a 55 years impasse, a Higher Education School was finally created in order to teach electrical communication technologies and graduate Telecommunication Engineers. By then, it was the year of 1920 , but this is other different story to be told in other different paper.

\section{CONCLUSIONS}

- First telegraph experiences in Spain took place in early $19^{\text {th }}$ century, although its real development did not start until 1852.

- A public exploitation for electric telegraphs in Spain was selected, but two Ministries challenged to gain the control: Interior and Public Works.

- The Body of Telegraphists was established in 1856 in order to manage and operate the electric telegraph service in a first moment, and later to build and develop a national-wide electric telegraph network.

- The Body of Telegraphists was incorporated to the Ministry of Interior, being the first group in obtaining a nationally recognized professional qualification for the development of electrical communications in Spain.

- In late 1857 , there were already deployed $5,381 \mathrm{Km}$ of telegraph lines, 101 telegraph stations and 42 of 50 Spanish province capitals connected.

- Although telegraphists did not have a higher education degree, they claimed to be considered as Engineers. They finally got the status in 1920 as Telecommunication Engineers.

\section{REFERENCES}

[1] S. Olivé Roig, El Nacimiento de las Telecomunicaciones en España. Madrid: FUNDETEL, 2004.

[2] Royal Decree signed on 8 January 1931, Gaceta de Madrid, n. 10/1931, pp. 234-235, 10 January 1931.

[3] Charles J. Esdaile, Spain in the Liberal Age, from Constitution to Civil War, 1808-1939. Malden, Massachussetts: Blackwell Publishers, 2000.

[4] Eurotelecon-90, Exposición Histórica de las Telecomunicaciones, Catalog of the Eurotelecom-90 Forum. Madrid: Ed. Ministerio de Transporte, Turismo y Comunicaciones, 1990.

[5] A. Suárez Saavedra, Tratado de Telegrafía, vol. 1. Barcelona: Imp. Jaime Jepús Roviralta, 1880.

[6] A. Pérez Yuste, "Salvá's Electric Telegraph Based on Volta's Battery," Proc. of the IEEE History of Telecommunication Conference, Histelcon 2008, pp. 6-11, Paris, 2008.

[7] Royal Decree signed on 27 November 1852, Gaceta de Madrid, n. 6736/1852, p. 1, 1 December 1852.

[8] Royal Decree signed on 28 June 1853, Gaceta de Madrid, n 182/1853, p. 1, 1 July 1853.

[9] Royal Decree signed on 6 October 1852, Gaceta de Madrid, n. 6681/1852, p. 1, 7 October 1852.

[10] A. Bahamonde Magro, et al., Las Comunicaciones en la Construcción del Estado Contemporáneo en España. Madrid: Secretaría General de Comunicaciones del Ministerio de Obras Públicas, Transporte y Medio Ambiente, 1993.

[11] Royal Decree signed on 22 April 1855, passing the 1855 Telegraph Act, Gaceta de Madrid, n. 843/1855, p. 1, 24 April 1855.

[12] Royal Decree signed on 31 March 1856, passing the 1856 Body of Telegraphists Regulation, Colección Legislativa de España, Primer Trimestre de 1856. Madrid: Ed. Imprenta Nacional, 1856.

[13] Royal Decree signed on 26 July 1856, Gaceta de Madrid, n. 1309/1856, p. 1, 4 August 1856.

[14] Royal Decree signed on 31 July 1856, Gaceta de Madrid, n. 1312/1856, p. 1, 7 August 1856.

[15] Royal Decree signed on 15 April 1857, Gaceta de Madrid, n. 1565/1857, p. 1, 18 April 1857.

[16] Royal Decree signed on 14 December 1864, Gaceta de Madrid, n. 351/1864, p. 1, 16 December 1864.

[17] Royal Decree signed on 3 June 1866, passing the 1866 Body of Telegraphists Regulation, Gaceta de Madrid, n. 158/1866, pp. 1-2, 7 June 1866. 